\title{
Snow accretion on, and removal from, railway car bodies
}

\author{
Toshishige Fujir, Toru Endo and Toshiaki Imai \\ Railway Technical Research Institute, 2-8-38, Hikari, Kokubunji, Tokyo 185, Japan
}

\section{SUMMARY}

To determine the amount of heat needed to prevent snow from accreting on the body of a running Shinkansen railcar, tests of snow accretion under conditions close to operation in Shinkansen were carried out in a cold-room using a wind-tunnel, a snow-feeder apparatus, a waterfeeder apparatus and a panel-heater.

The cold-room tests were run at air temperatures of $-1^{\circ},-5^{\circ}$, and $-10^{\circ} \mathrm{C}$, wind speeds of 5 and $10 \mathrm{~m} \mathrm{~s}^{-1}$ (wind direction: normal to the panel-heater), snow-drift intensities of $0.05,0.2,0.6$ and $1 \mathrm{~g} \mathrm{~cm}^{-2} \mathrm{~min}^{-1}$, heating rates of $0,0.5,1.5,2.5$ and $3.5 \mathrm{~kW} \mathrm{~m}^{-2}$, and liquid water contents (ratio of water mass supplied with the waterfeeder apparatus to snow mass supplied with the snow- feeder apparatus) of $0 \%, 5 \%, 10 \%$ and $20 \%$ for each intensity of drifting snow.

At $10 \mathrm{~min}$ after the tests had started, states on the surface of the panel-heater were classified into the following six modes: (1) water adhesion, (2) snow-jam accretion, (3) snow accretion, (4) ice accretion, (5) icefilm formation, and (6) no accretion.

Impact forces were measured using equal weights of snow containing no water and snow-jam mass filled with water. The maximum impact force of a snow-jam mass was smaller than that of a snow mass.

Results from these tests indicated that the heat needed to melt accreted snow or to transform it into a snow-jam is about $3.5 \mathrm{~kW} \mathrm{~m}^{-2}$, and the heat capacity to melt accreted snow at a station within $90 \mathrm{~s}$ is about $1.5 \mathrm{~kW} \mathrm{~m}^{-2}$.

\section{Feasibility study of a "snow dam" concept}

\author{
Norio Hayakawa, Tosio KoIke, \\ Department of Civil Engineering, Nagaoka University of Technology, Nagaoka, Niigata 940-21, Japan \\ ISAO KAMISHIMA \\ Takada Construction Office, Hokuriku District Construction Bureau, Ministry of Construction, Joetsu, Japan
}

\section{SUMMARY}

Historically, the use of snow for human well-being has been mainly for recreation, such as skiing. Recently in Japan, there is a mounting interest in using snow for various purposes that better serve life in snowy areas. This paper reports a feasibility study of a totally new idea of gathering and storing snow as a "snow dam", and using the delayed meltwater to supplement water demand in summer.

The idea is not to build a structure that stands like a concrete dam, but to gather snow in gorges where siting conditions and technology are appropriate, for example in a region of very heavy snow where there is an urban area to be served which in summer runs short of water.

Western parts of Japan's main island receive a large quantity of snow due to the seasonal wind blowing across the Sea of Japan. The city of Arai in this area is chosen to be the study site, on the western side of which is the Nakano River basin, bounded by $2000 \mathrm{~m}$ high mountains where the erection of snow dams is proposed.

Technology is needed both to gather snow in gorges and to reduce rates of melting, so that water can be extracted to provide a supply when it is most needed.

Various kinds of technologies are reviewed. It is concluded that none can at present furnish a quantitative answer as to how much snow can be gathered.

Technology to control and delay the melting consists of treating snow dams and predicting snowmelt runoff. The latter requires research on small-scale runoff analysis in a dam located deep in a gorge, and the calculation has to be done well through the summer season. A model developed for this purpose is applied to the study site.

Snow and avalanche data have been collected in the Nakano River basin. Several gorges have been selected as possible snow-dam sites, and the model assumes that a 
reasonable amount of snow has been gathered in them. A distribution model has been applied to these conceptual snow dams, which takes into account both topographical and meteorological distributions, as well as that of solar radiation within the basin. The model combines a calculation of net heat influx into the snow surface (Koike and others, 1985) with a calculation of direct and indirect runoff components ( $\mathrm{Lu}$ and others, 1989), routing the former down the meshed channel network and the latter with the lumped model.

A snowmelt calculation started on 3 April 3 1990, demonstrates that the conceptual snow dams increase summer stream flow well into August.

\section{REFERENCES}

Koike, T., Y. Takahasi and S. Yosino. 1985. A study on modeling of snowmelt distribution. Proc. Jpn Soc. Civ. Eng., 363, 165-174.

Lu, M., T. Koike and N. Hayakawa. 1989. Distributed rainfall-runoff model using radar rain gauge. In Proceedings of the 33rd Japanese Conference on Hydraulics. Tokyo, Japan Society of Civil Engineers, 91-96.

The accuracy of references in the text and in this list is the responsibility of the authors, to whom queries should be addressed.

\title{
Use of Gaz.ex for Japan's central mountains
}

\author{
ISAO KAMIISHI, \\ ARGOS Co. Ltd., Gakkouchou Arai, Japan \\ AKIMICHI IIYOSHI, \\ Tokyo Club Inc., Sanbongishinden Arai, Japan \\ Norio Hayakawa, \\ Nagaoka University of Technology, Nagaoka, Niigata 940-21, Japan \\ KUNIO KAWADA \\ Toyama University, Toyama 930, Japan
}

\section{SUMMARY}

Japan's central mountains receive a large quantity of snow, due to winter winds blowing across the Sea of Japan. This snow is generally heavy and very wet. In this region, development of large-scale ski areas is increasingly common in recent years, making development of avalanche control an urgently needed technology.

Gaz.ex, an avalanche-blasting device recently developed in France, appears a promising technology for this environment, although it has been used mainly in the area where snow is light and the weather quite cold. Gaz.exes of different capacity have been installed and tested on Mount Ougenashi, Niigata Prefecture of Japan.

The eastern slope of Mount Ougenashi (elevation $1429 \mathrm{~m}$ ) is being developed as a ski area. On this slope, two Gaz.exes were installed in December 1991 at an elevation of about $1200 \mathrm{~m}$. Numbered A-1 and A-2, their capacities are, respectively, $3.0 \mathrm{~m}^{3}$ and $2.6 \mathrm{~m}^{3}$. In normal years the maximum snow depth reaches almost $7 \mathrm{~m}$ at this location. Deposited snow quickly turns to compacted or granular snow, with density of $0.3-0.4 \mathrm{~g} \mathrm{~cm}^{-3}$. Minimum temperatures are $-10^{\circ} \mathrm{C}$ at this location.

More than a dozen test firings of these Gaz.exes in January and February 1992 failed to set off avalanches. Most were done under clear skies and in daytime, when snow surfaces became hard-crusted.

Success was obtained on 27 February 1992, when at
A-1 an avalanche was released with width of $100 \mathrm{~m}$, flowing down to the valley bottom and then uphill over the other side of the valley to come to a stop $600 \mathrm{~m}$ from

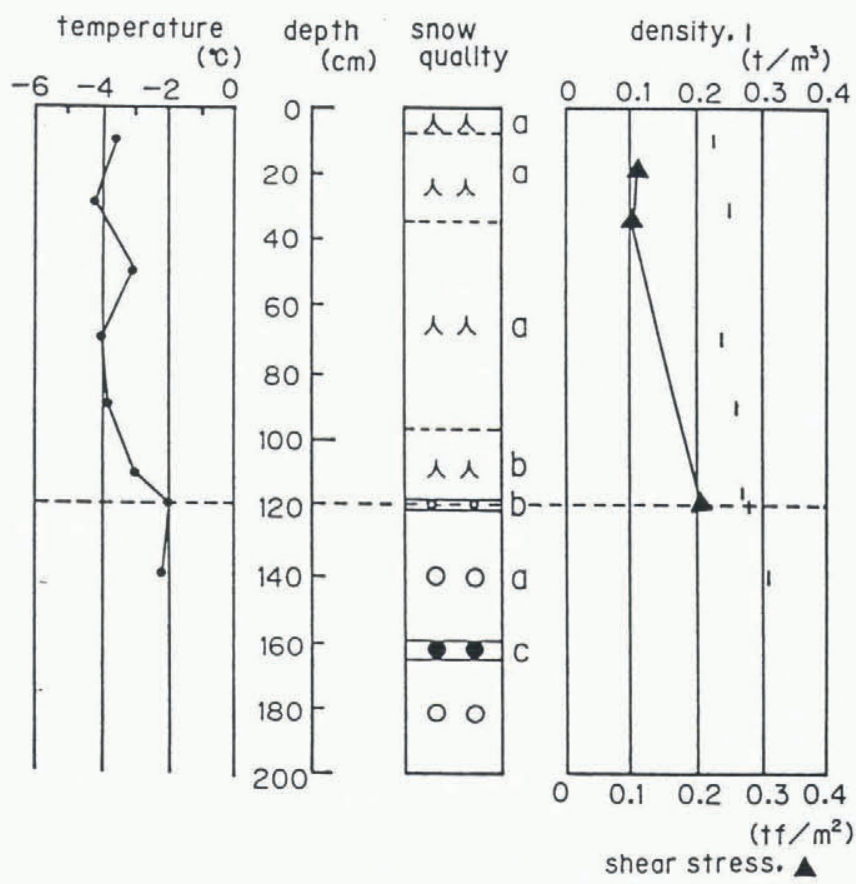

Fig.1. Snow-pit observation at $A-1$. 